\title{
"Things Can Be Done Here That Cannot So Easily Be Done Elsewhere": Jane Calvert Talks with Arie Rip
}

\author{
JANE CALVERT \\ UNIVERSITY OF EDINBURGH
}

ARIE RIP ${ }^{2}$

UNIVERSITY OF TWENTE

\begin{abstract}
In this interview, Arie Rip talks to Jane Calvert about his life in STS and the history and future of the field. He begins in the late 1960s, when he started teaching a course in "chemistry and society." He then gives a first-hand account of the formation of the European Association for the Study of Science and Technology (EASST) and the Society for the Social Studies of Science (4S), and the growth of research in the "melting pot" that STS became. He goes on to discuss recent work on new and emerging technologies and responsible research and innovation. His narrative shows the connections, historically and in the present, between the different strands of STS, including sociological work, science policy and innovation studies. He argues that we are seeing a "mainstreaming" of STS as it permeates other academic disciplines and arenas such as government agencies and charities. He suggests that this mainstreaming may mean STS will disappear as an independent discipline. In her reflection following the interview, Jane Calvert focuses on Rip's point that STS is both a social movement and an academic discipline. She argues that this raises questions about what type of work we want to do as STS researchers, and how much freedom we have to choose.
\end{abstract}

\section{Keywords}

constructive constructivism; reflexive modernization; mainstreaming; pedagogy; European Society for the Study of Science and Technology (EASST); Society for Social Studies of Science (4S)

\section{Grew Up Doing STS in a Chemistry Department}

JC Can I start by asking how you first became involved in STS?

'Jane Calvert, Email: jane.calvert@ed.ac.uk

. Arie Rip, Email: a.rip@utwente.nl

Copyright (c) 2018 (Jane Calvert, Arie Rip). Licensed under the Creative Commons Attribution Non-commercial No Derivatives (by-nc-nd). Available at estsjournal.org. 
AR At the time, in 1969, what we now call STS was at an early stage. There wasn't really a field in the strong sense, although there were journals-Research Policy, since 1967, and Social Studies of Science, which at that time was called Science Studies-and there were groups in Sussex, in Edinburgh, there was Liberal Studies in Science in Manchester. I got into STS laterally; I was drawn into it rather than making a choice. I had studied chemistry in Leiden, was interested in chemistry, but also knew that I wouldn't be just a chemist. I wanted a bit more. Since I didn't know sociology existed, I thought maybe I should do a first degree in philosophy. That was a conscious choice, but I didn't like the degree very much. Although I liked some elements of philosophy, it was very dry for me. But I had a mind which was able to do philosophical thinking, conceptual analysis and so on, in contrast to some other people in chemistry who were much better at actually doing things, using their hands. I got a first degree in philosophy, decided to continue, but I didn't really know what to do with my life. Then it so happened that the student movement, which linked up with the young academics movement at the time--19681969--came to a head in the Netherlands in 1969. The students in the chemistry department wanted a special course in chemistry and ethics. Their idea was that there was more to chemistry than just the science. For them ethics included politics and practical work, for example related to the war in Vietnam. But there was nobody within the philosophy department who was acceptable to the students and was willing to do it, so the chemistry department looked to their own staff. I had done my master's degree in chemistry by then and I was in the department of physical chemistry, and still thinking about what I should do. The chemistry department asked me to be responsible because of my philosophy degree. I said "yes" even if I didn't know what it would be, but it sounded like an opportunity. It was called "chemistry and ethics" originally, but I wanted it to be called "chemistry and society." That was agreed, and I never looked back.

JC Why did you want to call it "chemistry and society"?

AR I didn't like ethics, I thought it was too individualistic and too simplistic and too closely linked to religion.

JC So the initiative came from the students?

AR Yes, and the students got the department of chemistry to agree (at the time, the department was afraid of student protests, and willing to make concessions). It was really like a Gideon's Band that first year, and the second year as well. Instead of having regular courses, which I couldn't give anyway, we had projects of various kinds, and I was supporting the students and thinking with them. I always said at the time that my interest is not in the revolution-which was common terminology at the time because Marxism was the fashion-but an intellectual interest in: "what's happening here? What's happening in science in society?" And I continue to take that position. I might be a little bit of an activist sometimes, but only a little bit. I'm still very strongly intellectually motivated, so I tend to be reflexive. So I got into the field laterally. The second step was my starting to read widely and creating background readings for the students based on my own selections (Thomas Kuhn, of course, but also J.D. Bernal, and 
then Jerry Ravetz). There was work in the UK and the US at the time, and that's where the journals were. I got a more systematic introduction because of what happened at the Free University in Amsterdam, where a physics professor Egbert Boeker pushed for a department for social aspects of science. As part of that enterprise, he went to the Science Policy Research Unit (SPRU), which then still had their history, philosophy and social studies of science (HPSS) group with Roy MacLeod. When Boeker came back he set up an introductory course at the Free University, given by people from SPRU and HPSS, so Roy MacLeod was there, Chris Freeman, Keith Pavitt-those three I definitely remember. I followed the course but also talked with Boeker about how to set up these things in universities more generally, not just in the Free University. We actually published a little piece in the Dutch professional magazine for universities, which came out in July 1973. By that time, I had taken the initiative for national-level meetings of people (young staff, advanced students) active in "science and society" teaching and activities. And in the Leiden chemistry department, we were working to create a full program, with projects and courses as part of the compulsory curriculum in the first two years. In parallel to that I started to do some dedicated research, and to familiarize myself with the literature. Both Boeker and I got into contact with individuals from the UK, in particular around the SISCON projects that were financed by the Leverhulme Foundation. "Science In a Social CONtext" developed training modules about science in society in a number of universities. Often, graduates were hired to do the work who had a background in natural science or engineering and were moving into social science, particularly science, technology and society. SISCON and the UK/Netherlands link, which was starting to solidify, allowed me to get to know people in the UK, people like Brian Wynne and John Law and Steve Woolgar-the first generation, you could say. And like in the Netherlands, there were older people who were in the universities already and overseeing the SISCON projects. So you had Ernest Braun in Aston and people like Mike Gibbons in Manchester, and David Edge, of course, in Edinburgh. We started to have Anglo-Dutch conferences on science in society-one in 1978, the other one in 1982. So you can see part of my trajectory, which was at the time very much defined in terms of the science, technology and society movement. I have to add that the movement was complemented by academic work which was very visible in the UK and became more and more visible in the Netherlands, partly because of my own interests." In the 1970s I had already started to do research which was relevant to STS questions and I also started to publish and became involved, originally through Sussex, and particularly Roy MacLeod, in European-wide activities, which were then labeled PAREX, which started as a Paris/Sussex link, but became much broader. The Germans in particular came in, and the Dutch of course, particularly me. The PAREX activities were originally funded by the UK Social Science Research Council and the Maison des Sciences de l'Homme in Paris. In a

${ }^{3}$ Selected papers were published as proceedings by VU Bookshop, Amsterdam.

"For the two streams of STS (movement and studies) see Arie Rip, "STS in Europe," Science, Technology and Society $\underline{4}(1)$ (1999) 73-80. 
few steps, PAREX turned into the membership organization EASST (European Association for the Study of Science and Technology); I was instrumental in that transformation. Actually I've written up most of that story in a paper in the EASST Newsletter some time ago. By then, the late 1970s, my move into STS as an academic field was complete. There were a number of other things that happened in the Netherlands which are relevant for my career and to some extent relevant for the field, in particular how in a number of steps a priority for science dynamics was created, including a dedicated Chair eventually located in the University of Amsterdam. The whole operation was a stimulus for academic work in STS in the Netherlands. In the 1980s and early 1990s the Netherlands was really the strongest country per capita for STS. I'll say one thing more which is actually anticipating the question of how the field developed. I grew up doing STS in a chemistry department and being recognized by all the people there as a chemist, and that has continued in my life, so later on I could be seen as "safe" because I was a chemist originally--I still "smelled" like a chemist. But on the other hand, scientists and policy makers could not always locate me, partly because STS was new and seen as probably critical. They trusted me but still they had doubts. I remember that I published my second year lecture course as a book, which was something of a success, ${ }^{\circ}$ and one of the chemistry professors who was quite sympathetic to the move towards society, read the book and said: "Isn't it a bit relativistic? You never talk about truth." Then I realized that I had used the word truth only once in the whole book and then between quotes-so I was already doing STS in the pragmatic constructivist mode! By chance I was present at the founding meeting of the $4 S$ (Society for Social Studies of Science) because of a colleague of mine at Cornell University had proposed that I come over and participate in a project of his on science advisory councils. That was in November 1976, at the time and place where 4 S was established. So I went to the meetings. I knew Peter Weingart already from PAREX. I first saw Bruno Latour there. That was actually his first public appearance in STS-I still have his paper with core points later published in his Laboratory Life, and I could tell you stories... By the end of the 1970s I was into the USA situation as well. I had contacts already because of the science in society movement, but I also had contacts through the academic part of STS. So it was a matter of just being part of the field, not just following it but also helping to develop it because I had my interests and my priorities.

\section{The Phrase "Social Responsibility" Was in the Air}

JC Two things that strike me are "why" questions. Firstly, why was Boeker able to create a department of social aspects of science?

"Compare R.P. Hagendijk, "Science dynamics" in the Netherlands. Science and Public Policy (Dec 1982), 292296.

'Arie Rip, Wetenschap als Mensenwerk. Over de rol van de natuurwetenschap in de samenleving (Baarn: Ambo, 1978; second edition 1980). 
AR At the Free University? Because it was a denominational university, a university for strict reformed Christians, so they always had things like obligatory courses in the philosophy of Reformed Protestantism. The Free University wanted that kind of thing and the effect of the student movement was that they wanted to have something concrete and relevant to society. Then, because this whole notion of the social aspects of science had become visible, that was taken as an occasion to create a Chair within the faculty of science. So it was partly the spirit of the times and partly the particular initiative of this guy Egbert Boeker. He and I published a paper in Social Studies of Science in '75 on scientists and social responsibility in the Netherlands, which was an intellectual attempt to see what the history and the pre-history was of what we were doing then. The phrase "social responsibility" was in the air because the Dutch law on higher education from 1960 had in its opening articles a sentence that enjoined the university to pay attention to societal responsibility. That was not taken up until 1970 when the student movement started to refer to it as a justification for paying explicit attention--having science in society courses, for example. So that notion of social responsibility became important in that transition phase between 1969 and 1975 when almost all the universities created something like a "science in society" group, and sometimes a number of them in the various science departments. In terms of the history of STS in the Netherlands, and partly the history of the field, it created quite a lot of positions and people who were filling those positions who were in the science, technology and society movement because they were teaching, they were engaging with society, they were linked to the science shops and so on, but they were also starting to do academic work. There were some people who tried to articulate what social responsibility could be, and should be, and I was one. I was intrigued by the fact that that phrase appeared in the law, and how it came to be there and also what people were thinking of, or referring to, when they were talking about social responsibility, because people use the same term for different things. I actually wrote my PhD thesis on the societal responsibility of chemists. I didn't continue with that topic after I defended my PhD (because science dynamics was taking up most of my attention), although I had done some innovative work there by showing that social responsibility is actually part of a responsibility language which allows people to talk about roles and responsibilities; it's not something in itself. I'm saying that because first in nanotechnology with the whole notion of responsible development, and now with responsible research and innovation (RRI), I'm back where I came from, but with the advantage of all the intervening years of experience. And I'm now pushing for that idea that I put forward in my thesis but never published. I've used part of it in an article which is published in Life Sciences, Society and Policy, "The Past and Future of RRI.": There you see a discussion of the actual use of the term "responsibility" as a responsibility language, plus the notion of a "division of moral labor."

" Arie Rip and Egbert Boeker, "Scientists and Social Responsibility in the Netherlands." Social Studies of Science 5 (1975) 457-484.

${ }^{8}$ Arie Rip (2014) Past and Future of RRI. Life Sciences, Society and Policy, 10 (17). 
JC So how do you understand the origins of the field of STS?

AR At the time I was just encountering STS, but already seeing this distinction between the movement side and the academic side. Then there are two responses to your question; one is immediate in terms of "what do we see happening in STS?" But it is also a response (which would also apply to the history of science and philosophy of science) to the rise in importance of science and then of technology in society. There are precursors in sociology and in intellectual debate in the 1920s and 1930s. By the 1960s, social studies of science was visible. If you look at the history of the field in an academic sense from the 1970s to the 1990s you see a movement from the earlier macro-level studies, often in the Mertonian social system of science tradition, to the Kuhnian focus on paradigms at the meta-level and the study of specialties in the 1970s, to lab studies and ethnography since 1979, down into the micro, and then a return up again to the macro.' It is not the whole story of the field, because the STS movement created (and creates) all sorts of horizontal links. Generally, in the 1960s and 1970s there was a "melting pot" effect, where development studies, peace studies, and gender studies or women's studies were all part of the mix. This tells a core STS story. It encompasses the notion of pragmatic constructivism that I tend to push as characteristic for core STS, and it also links up with mainstreaming - that lots of the work that once used to be typically STS is now actively pursued in many other disciplines. So this is one story of the field. The other story continues the response to the importance of science and technology in society, and links with broader societal developments, and how STS became important because of them, sometimes in terms of oppositional movements. Now I tend to think in terms of the notion of reflexive modernization, as Ulrich Beck has developed it over time. I'm not too keen on his terminology of second modernity and his claim that there is a historical secular break in the 1970s and 1980s from first modernity to second modernity. But I do think there is a movement towards reflexive modernization, with a cusp in the late 1970s and early 1980s. The fact that STS became important as an academic field, and kept some of its movement character, now appears in how it is becoming integrated into the governance of science, including technology assessment. So now it is actually part of how reflexive modernization gets settled.

\section{Coups and Countercoups}

JC Where does the Edinburgh Science Studies Unit and the Strong Program fit in to the origins and trajectory of STS?

AR It was, I suppose, the combination of David Edge and Barry Barnes. Barry Barnes was the Young Turk fighting against the so-called Mertonian approach. Merton's reputation, rather than his actual activities in STS, was seen as a constraint. And then David Edge,

"Arie Rip (2005) Haven't we got all the theory we need? Paper prepared for the workshop "Middle Range Theories in Science and Technology Studies." Amsterdam, 27-29 April 2005. 
who came from astronomy and the $\mathrm{BBC}$, so more the public understanding and public communication side, but interested in the STS movement, but also in the academic side. And then fairly soon other people started to join them, in particular David Bloor, who became famous with the Strong Program. That was, at the time, a part of the overall movement to the meso-level, to paradigms and specialties; there was still very little work on the micro level, the lab-study stuff. There were interviews with people, of course, so there was some micro work, but the main interest was in the specialties and how these were shaped, including the whole internalism/externalism debate, which was quite strong at the time, and was conducted in terms of specialties, not in terms of laboratories. That was how I was formed in STS, although I was very happy with the turn to the micro. When Laboratory Life was published, I wrote Bruno Latour a fan letter. I am also a bit of an anthropologist but then a sort of multi-level anthropologist and sometimes a bit impatient with the micro level anthropologists. I am an anthropologist by nature really, not just by academic persuasion. I was also an anthropologist in my own laboratory. I had been noticing things in the chemistry lab which were very similar to things that Bruno wrote about. Anyway, you asked, where is Edinburgh in this scheme?

JC Yes.

AR I'd been talking with David Edge a lot through the SISCON meetings, also because David was mobilizing people to contribute to Social Studies of Science. And I became collaborating editor at one time and also something of a confidant to David, not the only one, but I was one. Partly because of David's link with the science in society movement, he saw me as being in that movement as well. David was also the instigator of my becoming president of $4 S$ in 1990-after being future president for a year. That was one of the last parts of the big struggle against the Mertonians because you had these Young Turks from the UK, and some of them in the US, who were becoming visible and stronger. There was a reaction from the Mertonians like Jerry Gaston, who worked in the University of Texas, and the two brothers Cole. There had been coups and countercoups, like the one in Toronto at the $4 \mathrm{~S}$ meeting in 1980, but also struggles in the International Sociological Association which had a Research Committee on sociology of science, and there you had the Mertonians and the counter-Mertonians. After the first debates the Young Turks didn't define themselves as counter-Mertonians any more, they were just important in their own right, but in the first few years (early-mid 1970s) it was just going against Merton. But in terms of people and linkages and networks and coalitions, the difference remained strong. In 1988, Jerry Gaston said that he would put himself up as a candidate for the $4 \mathrm{~S}$ presidency, which was seen as an attempt at a coup. So David came to me and said, "Arie, won't you be the other candidate for the presidency because you're not seen as being polemically against Merton and the Mertonian approach, and there are good vibrations about you." Indeed, I never went into the big debates, although I was part of them intellectually. So I said "yes," and I won and I was president. I was then also working a lot with Tom Gieryn, because he had been secretary/treasurer with David Edge and some things were set in motion, like taking over STHV, which actually 
happened when I was president. Tom came from the Mertonian tradition but had moved away. Wes Shrum became secretary at the same time as I became president and Wes was sort of not in the fight, although he was sympathetic to the new approaches, definitely. Then Tom and I started talking, also because we were working with Harriet Zuckerman to get more linkages with the East Coast establishment: New York Academy of Arts and Sciences, and National Academy of Sciences. Harriet was important there, and she was also finding people at $4 \mathrm{~S}$ who had better links, including links with the East Coast establishment, which was not just Mertonian, it was also the science policy establishment. So we talked Harriet into running for president of $4 S$ three years later, but we had another situation by then, with new strengths of the non-Mertonians and some appreciation from the science policy establishment. She won. The struggle was not completely over, as in the 4S Annual Meeting in November 1993 where Steve Cole's book Making Science, including an extended criticism of the constructivist approach, was the occasion for an author-meets-critics session. But it was tapering out. This is going much further than Edinburgh, but Edinburgh through David was also going further than just Edinburgh. So if you ask what my link with Edinburgh was, most of my answer is in terms of David and internationally. I was very happy with what Barry Barnes always did, and still am, although I see limitations as well. I couldn't get excited about the strong program because interests become almost given there, rather than being constructed and reconstructed all the time partly through science and technology.

\section{Pragmatic Constructivism and the Mainstreaming of STS}

JC This is fascinating; I didn't realize there were so many connections! My next question is about the path that STS has taken since the origins and any reflections you have on that path.

AR I mentioned two important parts of the path already, which were the stabilization of a core STS approach, which you can call pragmatic constructivism, and the other thing-mainstreaming of what used to be a typically STS message, in geography, political science, in business studies, anthropology, everywhere.

JC What is the message?

AR Pragmatic constructivism. This is not just my personal point. In WTMC, the Dutch Graduate School of Science, Technology and Modern Culture, we have always been reflective about what we were doing also because we sometimes had to justify it. We've had our struggles, but at one moment when we had to go for re-accreditation as a graduate school. We spent quite some time doing an in-depth review of the field in the Netherlands, and internationally. From that review and discussions we came up with these two notions of pragmatic constructivism as a core, and mainstreaming as something that was happening without us being willing or happy about it, and definitely not us being initiators. There's also the Bruno Latour effect: Apart from his talent for writing wonderful stories and wonderful polemics, his book Science in Action was written 
as a sort of handbook at a time that the mainstreaming actually began. ${ }^{\text {" }}$ So people who were mainstreaming and looking around for a good overview, they went to Bruno's book, as if there was little or no alternative.

JC Why was there a demand for that type of mainstreaming?

AR If you want a short answer: Reflexive modernization. As to the path of STS, there's now also a much stronger recognition of, and acceptance of, links with policy, and even links with business. The latter has to do with new and emerging technologies, but the former has to do also with changes in policymaking, and reflexive modernization. To go back to my own work, I've always been in a bit of a grey zone because of my past, but also because I was interested in interacting with people who were making actual decisions, rather than just denouncing them as not recognizing constructivism. From the early-mid 1980s on I was already trying with a number of other people like Susan Cozzens and Ron Johnston and John Ziman to create STS/science policy studies as something which would be like a caucus in 4S. In EASST and in Europe more generally it was much easier to do that, but we had very little success in $4 \mathrm{~S}$. There was only interest when we had meetings in Washington DC because then we would have a lot of people from the agencies. We did do a major thing, which was the NATO Advanced Study School in Il Ciocco, which collected all the people from STS and science policy studies for two weeks in an Italian conference center. A book came out of that which is still very interesting to read, edited by Susan Cozzens primarily but with help from John Ziman, Peter Healey and myself." In terms of themes and topics, it didn't make much of a difference, but in terms of people and interactions it did make a difference. You could see that linkages were made in Il Ciocco--the name of that conference place still has some magic to it for people who were there. One thing that I pushed already in the 1980s discussions was my interest in the role of promises and expectations, not just in science, but also science policy. So, when I became a professor here in Twente and could occasionally define topics for $\mathrm{PhD}$ students, I strongly suggested to the PhD student Harro van Lente that he should work on expectations and promises. His thesis on promising technologies was one of the key starting points of this whole sociology of expectations and promises, which is now very well accepted, and Harro is still one of the key figures. I've put some new elements in it in some of my work on nanotechnology, like sociotechnical scenarios in Constructive Technology Assessment. This is all about what I called the grey zone that I was moving in anyway, but for the path of the field it is important that we now see it actually happening, particularly in Europe. The interest in new and emerging science and technology, in policy and in STS, is a very strong input in this whole move of the field of STS, but it's also about science institutions and how they have inertia but also want to move: they have problems doing so, so they need people like us. Also in the United

${ }^{10}$ Latour, Bruno (1987) Science in Action: How to Follow Scientists and Engineers through Society. Harvard, MA: Harvard University Press.

"Susan E. Cozzens, Peter Healey, Arie Rip, and John Ziman (eds) (1990) The Research System in Transition, Dordrecht: Kluwer Academic. 
States you see it happening, although there, because of the expertise orientation of American political culture, it has been reduced to a "science of science" program.

JC That relates to a question I have about the relationship of STS to other fields, like science policy, as you've mentioned. And the reason I feel an affinity to your work is because you do cover science policy, innovation studies, STS, the sociological side, and ELSA as well, so you cover all these sub-areas of STS.

AR The mainstreaming point indicates something of what is happening. The other thing is the melting pot. As I said before, the situation in the late 1960s early 1970s was a melting pot of crisscrossing issues and non-disciplinarity. All sorts of approaches and analyses could be mobilized, and disciplines were seen as a constraint, as counterproductive. For people from women's studies it could be very interesting to meet people from peace studies in one or another STS meeting. That to some extent still is an aspect of STS, that it is a melting pot. In the US, that was visible in the time that I was president of 4S. You had these strongly disciplinary associations--philosophy of science, history of science, history of technology - and then you would have STS, which for some reason was called social studies of science, but $4 \mathrm{~S}$ never was just the sociologists. For some time there was a rule to have the four societies meet together, every four years if I remember correctly. That was a big to-do because all these societies had their own constituencies and their own styles. There were a number of these four society meetings, and people were keen on continuing them but then the practicalities stepped in, but also the differences in how things were organized. The Philosophy of Science Association was very strict, you had to actively submit papers, and these would be refereed before you could present them. While $4 \mathrm{~S}$ was a happy-go-lucky society-you submitted the abstracts and there was very little selectivity. So lots of people could attend and interact. I remember at the time when people like Harriet Zuckerman (and myself in the background), but also Wes Shrum, were busy with these contacts with the other societies and with the East Coast establishment and so on, the Academies, that we started to emphasize that we are interdisciplinary, we are not just social studies of science, and you should take social studies of science in the broad sense-we are not referring to any particular social scientific discipline. A more academic version of the melting pot, you could say, which is still an element of STS: things can be done here that cannot so easily be done elsewhere.

\section{See STS as a Field in its Own Right Disappearing}

JC What about the relationship to science policy and innovation studies, do you see that as an easy relationship?

AR Easy?

JC Yes. Or are there different attitudes towards constructivism?

AR I personally don't find it difficult, but that's because of my past and present, but institutionally it is not always easy; particularly with journals it's problematic. So as a rule there are differences between Research Policy and typical STS journals, STHV and 
Social Studies of Science. But then there are some journals who do the sort of in-between stuff, like Technology Analysis and Strategic Management, German-oriented Science, Technology and Innovation Studies, in time also the new EASST journal. So there is space for in-between journals. If you look at the longer term you will see that Research Policy and Social Studies of Science overlapped in the late 1960s, early 1970s, and then, partly because of the stronger pressures on journals and publishers, they started to be much more specific in their profiles. At one moment Social Studies of Science became historical single case-study oriented, and Research Policy became very American and economicsoriented. While there are a few people who were working on both sides of the fence, institutionally, as I said, it was not an easy relationship, and that is still the case. At the level of departments it's different; there are departments who do both actually. But then often it is still divided between different people.

JC What about the relation with ELSA? Between STS and ELSA?

AR ELSA (Ethical, Legal and Social Aspects—of new technology, like in the Human Genome Project in the 1990s) will disappear so there's no need to get into that.

JC What, to be replaced by Responsible Research and Innovation (RRI)?

AR No, just by doing good work around new science and technology.

JC You think it will disappear?

AR RRI will disappear as a Brussels thing, not at the level of member states and organizations. It might change its acronym.

JC Do you see ELSA being STS work?

AR Lots of it was not STS. In the US with the human genome project quite a number of practitioners were straight sociologists and psychologists and sometimes economists and so on. ELSA opens the door to many disciplines and then they enter and do ELSA. But there is very little coherence other than that it must be related to the program that provides the funding for the research so it's an intellectually dependent area. RRI, although formally there is the same dependence, it does refer to major issues and transformations. ELSA was more like a tick box, identifying aspects and delving into them.

JC What about the move towards emerging technologies and your nanotechnology work? How does the emerging technologies field fit into the trajectory of STS?

AR I was a bit scathing about ELSA but at the time it emerged in the 1990s it was seen by STS as an important chance to get into the action, or at least closer to the action, and in that sense it's not too different from the recent interest in new and emerging technologies. So it can be quite exhilarating. It is a fashion you could say, and it gave birth to explorations of anticipatory governance.

JC Where do you see STS going in the future? If you had to do some scenarios for STS?

AR I think I see STS as a field in its own right disappear, in the sense that as a field it becomes too differentiated, but also particularly in the US, and to some extent in Europe, being reduced to a label for certain kinds of $\mathrm{PhD}$ studies. $4 \mathrm{~S}$ meetings have become gatherings of PhD students, to put it briefly, who are there to become visible on the job 
market. That's one thing that will happen. With changes in science policy there is more of a link to STS, also there is much more commissioned work for STS type people. So now you get into a situation where you have to think about the commissioned work, consultancy stuff, is that the sort of thing that you want to do? In Europe, the European Commission projects where people from our field can contribute are not very analytical. The survival will be in departments which have sufficient interdisciplinarity (and critical mass) to not suffer too much, and in terms of meetings, there is the melting pot effect. The melting pot function of STS is still there, and will remain, because we don't have all these disciplinary traditions and requirements upon us.

JC But if STS in its current form will disappear then what will happen to people with PhDs in STS?

AR It will remain as the label for a particular kind of PhD student study, an STS PhD study, or one that refers to STS. Then you sometimes need a supervisor from a regular discipline who is interested, but there are lots of them nowadays because of the mainstreaming. Or you need a department where there is still some sort of semblance of STS, which allows for those possibilities. It's really at the level of departments that things will continue, but then it might still be somewhat fragmented. So in our group in Twente, the STS component might actually disappear, not because we want it to, but because it so happens.

JC Are you worried about this or not?

AR I don't think you can change it, so I'm not prepared to worry about it. I am prepared to mention this, as a possible development in a way that people might actually take action, but I'm not in an institutional position to take action. As an example, I tried to set up a network for the combination of STS and Innovation Studies, but it was too difficult for people with actual positions, like Robin [Williams] and Mario [Biagioli], to be really active, so now it's disappeared more or less. I might become more active, but I'm limiting myself to RRI, because I might make a difference there; and also to some activities in South-Africa.

JC What kind of action should be taken?

AR I think it would be important to reposition the core of STS: while pragmatic constructivism is still a good phrase, constructivism often becomes short-circuited to "we must deconstruct!" PhD students think that they need to deconstruct to show what the world is like according to STS. I would-and I've said so way, way back-I would actually go for constructive constructivism, where you take as your example engineers who build things." So then the whole notion of design becomes much more important, not just design as it has developed in the design departments or in design jobs, and in journals like Design Studies, but the whole notion that you're actually building something that you don't know how it will perform, but you know that you're constructing it, that

${ }^{12}$ Arie Rip, Science and Technology Studies and Constructive Technology Assessment, EASST Newsletter 13(3) Sept. 1994, pp. 11-16. 
you want it to be robust. That notion of robustness is often absent in pragmatic constructivism. I'm using robustness whenever I can as an important ideal, as well as something very practical.

JC Does that relate to Latour's compositionist manifesto, the idea that critique has run out of steam, ${ }^{\text {i }}$ and we have to start building?

AR Yes, it's the same sentiment. And I've been arguing that for some time. Also because I wanted to have good interactions with people in the sciences and technologies, and still maintain or keep on telling my message. So I needed to be constructivist but I needed to show, and I can show in things that I've done, that I am a constructive constructivist.

JC Is there anything you would like to add, anything about the future of STS? One of the audiences for these interviews is the young people who are starting out in STS, and want to think about where it's going and where people would like to see it going.

AR I do think that mainstreaming is important, because STS then becomes more a label for a particular approach than a label for a particular community and field. You could say that it's the mission of STS to make itself superfluous. As Bruno Latour has always said, it is just a good way to do anthropology, at the meso or the macro level. In that sense, nothing to worry about. On the other hand people have invested in the field, in careers, in centers and so on, so there is a sort of natural inertia. Then there is this long-term thing that STS is a bit of an umbrella term, seen from the outside, although from the inside you do see a certain core, which is the core that refers to Latour but without the polemics, you could say. The other thing is that in the past what I've seen in the STS movement and also with academic STS--and that's coming back with some force at the moment-is that STS is seen as a helper in difficult circumstances. So when scientists or industrialists or policymakers don't know what to do, if they have difficulties that they cannot resolve in a straightforward way, then they call on STS because they are these curious guys, and they look at things in a different way - maybe they can come up with something? So my own experiences, but also if I listen to other people, is that we are called upon, but only intermittently, and in the meantime we have to survive in order to be able to do our job the next time around. So in that sense there should be a future, to survive in the meantime while policymakers or other important actors are not bothering about us. At the moment we are in a good situation because quite a number of actors are bothering about us. But these same issues also attract other kinds of people, say ethicists, consultants, etc. and there is some competition-RRI would be an example of this.

JC In terms of institutions for STS, if we adopt this role where we're a service provider, to some extent, when we're needed, what kind of institutions do we go back to in those times when we're not needed? Does it make sense to talk about building institutions for STS, or is that hypocritical?

${ }^{13}$ Latour B (2004) Why Has Critique Run out of Steam? From Matters of Fact to Matters of Concern. Critical Inquiry 30(2): 225-248. 
AR It's a bit hypocritical but it's OK. It's sort of a survival state, hibernating perhaps-no really that's not the truth--it's probably service teaching, some continuation of our own teaching and $\mathrm{PhD}$ students. Sometimes people find they need us, and that's our history in Twente, and also in other places, you get embraced, you do some interesting teaching and then after some time it's found less interesting and your space is reduced. But the balance may turn again.

JC If we're just teaching or helping policymakers when they're in trouble, how do we sustain our own autonomous endeavor? Or do we not have one?

AR No, I think that's where the mainstreaming comes in, and the success of the pragmatic constructivist approach. And more broadly, reflexive modernization may open up spaces where STS-oriented institutions can flourish continuously, not intermittently.

JC For PhD students does that mean that they will have to get jobs in anthropology or sociology or politics or business studies? Will they have to look to different fields?

AR Yes. But there are STS-oriented institutes. There was quite a growth of the field starting in the mid-90s. That has become a bit more stationary, even if there are pockets of growth, such as the big center in the Technical University in Munich. There's also growth outside the universities, in interstices in government agencies, but also in the charitable foundations, where STS trained people can survive or actually blossom.

JC Would that be a victory for STS?

AR It's almost like a fifth column. I've used the term when describing the situation in the Netherlands in the 1970s, where people from the STS movement in universities actually infiltrated some of the institutions, like government ministries.

JC It seems to be quite circular-not badly circular but nicely circular-because you started off talking about how you were involved in STS through teaching, or through being asked to teach, and you ended up talking about how we could perform teaching roles to keep ourselves going, with that pedagogical element being central.

AR I would rephrase that. There is the argument from Mike Gibbons, in their New Production of Knowledge book," which could be developed further: people with some higher education have become much larger in number than they used to be. So in that sense society is different, and there are new possibilities. Similarly with the various growth spurts of STS and STS teaching, there are now more people with some exposure to STS. That's also mainstreaming you could say, not in terms of disciplines and approaches, but in terms of people. When you're visible as an STS scholar (and/or intellectual/practitioner), you encounter people who have heard of STS, know something about STS, and are happy to meet you, and get a better view of STS.

JC Yes, but do you think it makes any difference, that exposure to STS?

AR I should say that this is an empirical indicator for people actually having been exposed to STS and remembering. But it makes a difference, when people are behind their desks or in their meetings, a little bit, sometimes.

${ }^{14}$ Gibbons et al. (1994) The New Production of Knowledge London Sage. 
JC Are you optimistic about the future of STS?

AR That is a hard question. Maybe I should say "OK I'm old and tired, and maybe that's why I don't mind if STS disappears." But I have an instinctive identification with STS. It's my kind of world. I fell into it. It was my world, and still is.

JC And STS is richer because of that. Thanks very much!

\title{
The Two Sides of STS
}

\author{
BY JANE CALVERT
}

This interview with Arie Rip is rich in historical detail and discusses many important ideas-such as mainstreaming and reflexive modernization-making it difficult to restrict the scope of this short reflection. But I have chosen to limit my comments to Rip's discussion of the two sides of science and technology studies (STS), which he describes as being both a political movement and an academic discipline.

One reason I have chosen this focus is because those of us who aim for a career in STS have to decide what type of researcher we want to be. There are choices to be made about how much of one's time and energy to spend engaging with scientists, engineers, policy makers, NGOs, and others, trying to influence the direction of scientific and technological developments for the "better," and how much time to dedicate to more traditional academic activities, which are often more highly regarded and rewarded by our peers. This raises broader questions about the responsibilities one has as an STS researcher, and the extent to which these responsibilities extend beyond the academy.

Of course, the "movement side" and the "academic side" of STS are not easily separable-and Rip's career is an excellent demonstration of how intertwined they can be. Their inseparability may be what keeps STS vital, both in its academic and its more practical contributions. However, it may be that STS's dual character will prevent it from coalescing and ultimately thriving as an independent academic discipline, which is something that Rip anticipates in the interview.

\section{The Interconnected History of the Two Sides}

Rip's account of the history of STS shows how it was the pedagogical interventions initiated by the movement side that provided the foundation on which the nascent field could establish an academic footing. In fact, the reason that Rip first became involved in STS in the late 1960s was 
because science students at the University of Leiden wanted to have teaching that was "concrete and relevant to society." However, once he started teaching, the path Rip chose to pursue was a more academic one. So it was the movement side that enabled him to develop his intellectual interests in the relationship between science and society.

Rip shows how the influence of the movement extended across the Netherlands. For example, in the early 1970s an opportunity arose to create a Chair of STS within the faculty of science at the Free University of Amsterdam. Similar positions were created in universities across the country. Once they were appointed, people in these positions started to do academic work.

This is not only a Dutch story; Rip shows that the interconnections between the two sides were key to the development of STS more broadly. He identifies David Edge, a founding member of the Science Studies Unit (SSU) at Edinburgh, as someone who had strong interests in both the science in society movement and STS as an academic endeavor. This surprised me because I had previously assumed that the SSU stood firmly on the academic side; but Rip's account shows that the history is not so straightforward, and that what might appear now to be different strands of STS were much more entangled in the recent past.

(As an aside, the interview with Rip revealed to me the connections between the different parts of my own rather haphazard academic history-moving from policy-oriented research at the Science Policy Research Unit (SPRU) at Sussex, to much more philosophical work in Exeter, and then to the sociology of science in Edinburgh. In his account Rip shows how some of the founder members of SPRU were present at the birth of organizations such as the European Association for the Study of Science and Technology (EASST) and the Society for Social Studies of Science (4S), and were much more connected to philosophically and sociologically inspired STS than own my experiences had led me to assume.)

Rip's account uncovers connections between the subfields of STS, but he also notes some past and present frictions between them. For example, he reflects that his own interests in policyrelevant work put him in a "grey zone," because "I was interested in interacting with people who were making actual decisions, rather than just denouncing them as not recognizing constructivism." Rip worries about the desire among some STS researchers to deconstruct everything, and argues instead for "constructive constructivism, where you take as your example engineers who build things." This might be a more useful formulation of constructivism for an engaged STS, particularly one that focuses on the politics of science and the social responsibility of scientists. These topics were central to the movement side of STS in its early days, and they appear to be in resurgence today under the heading of "Responsible Research and Innovation."

Rip also draws attention to the sometimes uneasy relationship between the different subfields of STS when he explains how he tried, with little success, to establish science policy studies in 4S, along with Susan Cozzens, Ron Johnston, and John Ziman. In contrast, this was something that was comparatively easy to do in EASST. In my own experience, it is still the case that there is less "user-engaged" or "policy-oriented" work in 4S than in EASST. ${ }^{\text {s }}$ It could be argued that the different orientations of $4 S$ and EASST reflect different ideas about what

${ }^{15}$ Although the recent "making and doing" strand at 4S meetings might be a counter-example. 
constitutes good and valuable work in STS. These are tensions that future STS scholars (particularly those who cross continents) will have to learn to negotiate.

\section{The Future of STS}

Rip thinks that policy-relevant work is an area where STS will continue to make inroads in the future. He notes how in the Netherlands in the 1970s, "people from the STS movement in universities actually infiltrated some of the institutions, like government ministries," and he sees this continuing today, partly because of interest in new and emerging technologies. This means that we are currently seeing growth in STS "outside the universities, in interstices in government agencies, but also in the charitable foundations, where STS trained people can survive or actually blossom."

Rip also observes that policy makers and scientific institutions often draw on STS expertise in order to overcome inertia. In this way "STS is seen as a helper in difficult circumstances," particularly "when scientists or industrialists or policymakers don't know what to do." It is the ability of STS researchers ("curious guys") to look at things in different ways that is valued by these groups. Rip thinks that this will result in more commissioned work for STS researchers in the future, but he points out that the downside of this type of research is that it is often short-term consultancy, which is not particularly analytical. This again raises questions about what type of work we want to do as STS researchers, and how much freedom we have to choose. Another problem is that this type of research is intermittent, so that between periods of demand it is necessary to survive by other means. Rip says that STS will get through this hibernation state by "service teaching, some continuation of our own teaching, and $\mathrm{PhD}$ students." Teaching, as in the early days of STS, seems to be one of the ways in which STS may be able to retain its foothold in the academy.

I have found reflecting on the two sides of STS very helpful for my own understanding of the field and its history, but I want to end by re-emphasizing their interconnectedness. Demonstrating the social nature of scientific knowledge--which is core to the academic side of STS—can itself be a politically radical move. As Rip has written:

even when scholars in science and technology studies do not do anything else but careful and distantiated study of science, and publish their findings in scholarly journals, they are still involved in issues which have societal and political repercussions. ${ }^{16}$

One thing I take away from the interview is that it is our responsibility to acknowledge the political dimensions of our research, and that this also applies to those who do not consider themselves to be doing interventionist work. The tension between the two sides of STS is a defining feature of our history and something that we will continue to live with as we move into an uncertain future.

"Rip, A (1999) “STS in Europe." Science, Technology and Society, 4, 1, p.74. 


\section{Author Biography}

Arie Rip studied chemistry and philosophy at the University of Leiden, and continued to do research in physical chemistry there. In the 1970s he moved to teaching and research on chemistry and society, as well as science, technology and society more generally, and helped to establish work on science dynamics, in the Netherlands and internationally. He was guest professor of science dynamics at the University of Amsterdam (1984-1987), before taking up a position as Professor of Philosophy of Science and Technology in the (now) School of Management and Governance of the University of Twente. He retired in 2006, but continues his projects, advisory work, and publications. Recently (2017-2019), and after an earlier stint as guest professor (1998-2009) he was appointed Extraordinary Professor at the Faculty of Arts and Letters of the University of Stellenbosch in South-Africa. Rip's work on science dynamics, technology dynamics, and constructive technology assessment is widely appreciated. He has also engaged extensively on topics such as varieties of knowledge production and their evolution over time, the history of technology in the Netherlands, and futures of the institutions of science. He has participated in R\&D evaluation of programs, agencies, research groups and centers in a number of countries. He also led the Technology Assessment and Societal Aspects of Nanotechnology sub-program in the Dutch National R\&D Consortium on Nanotechnology, 2003-2011. He was secretary-treasurer of the European Society for the Study of Science and Technology (EASST), 1982-1991, and President of the Society for Social Studies of Science (4S) in 1988 and 1989. He was a member of a number of EU High-Level Expert Groups, including Foresighting the New Technology Wave, 2004; Science and Governance, 2005-2006 (see the Report, Taking European Knowledge Society Seriously); and MASIS, 2008-2009 (see the Report Challenging Futures of Science in Society). Since 2014, he has been a member of the Horizon 2020 Advisory Group on Science With and For Society/Responsible Research and Innovation (the first two years as chair). By the end of 2017, his publications amounted to more than 80 (co-) authored articles in peer-reviewed journals, 110 (co-) authored chapters in scholarly books, and 20 (co-) authored or (co-) edited books. A collection of papers that spans the breadth of Rip's work on Futures of Science and Technology in Society will be published by Springer in early 2018. Rip has supervised more than fifty PhD students. In 2016 he received the Mentoring Award of the Society for Social Studies of Science (4S).

\section{Author Biography}

Jane Calvert is a Reader in Science, Technology and Innovation Studies at the University of Edinburgh. She did her PhD at the Science Policy Research Unit at the University of Sussex, during which she participated in the WTMC summer school at the University of Twente in September 2000, organized by Arie Rip. She did postdoctoral research at the ESRC Centre for Genomics and Society at the University of Exeter. Her current research project, funded by a European Research Council Consolidator grant, focuses on attempts to engineer living things in 
the emerging field of synthetic biology. It investigates the movement of ideas, practices, policies and promises from engineering into the life sciences, and, more reflexively, examines the ways in which social scientists have been mobilized as part of this endeavor.

\section{References}

Cozzens, Susan E., P. Healey, A. Rip, and J. Ziman. Eds. 1990. The Research System in Transition. Dordrecht: Kluwer Academic.

R.P. Hagendijk, "Science dynamics" in the Netherlands. Science and Public Policy (Dec 1982), 292-296.

Gibbons, Michael, C. Limoges, H. Nowotny, S. Schwartzman, P. Scott and M.Trow. (1994). The new production of knowledge: the dynamics of science and research in contemporary societies. London: Sage.

Latour, Bruno.1987. Science in Action: How to Follow Scientists and Engineers through Society. Harvard, MA: Harvard University Press.

Latour, Bruno. 2004. "Why Has Critique Run out of Steam? From Matters of Fact to Matters of Concern." Critical Inquiry 30(2): 225-248.

Rip, Arie. 1978 (2 ed 1980) Wetenschap als Mensenwerk. Over de rol van de natuurwetenschap in de samenleving. Baarn: Ambo.

Rip, Arie. 1994. "Science and Technology Studies and Constructive Technology Assessment." EASST Newsletter 13(3) Sept. 1994:11-16.

Rip, Arie. 1999. "STS in Europe." Science, Technology and Society 4(1): 73-80.

Rip, Arie. 2005. "Haven't we got all the theory we need?" Paper prepared for the workshop "Middle Range Theories in Science and Technology Studies," Amsterdam, 27-29 April 2005.

Rip, Arie. 2014. "Past and Future of RRI." Life Sciences, Society and Policy 10 (17).

Rip, Arie and Egbert Boeker. 1975. "Scientists and Social Responsibility in the Netherlands." Social Studies of Science 5 (4): 457-484. 